\section{Conclusion}

In this paper it has been argued that among the three durable solutions to refugee problems, integration of the Mozambican refugees into the Malawian society seems the most plausible solution for the time being, at least until peace and security is fully restored in Mozambique. Refugees are resourceful and every effort should be made to encourage self-reliance. This can best be achieved by introducing various developmental projects that will help them generate income. Donor agencies must realize that concentration on relief aid alone is insufficient when assisting refugees. However, the complex issues of refugee participation, equal membership within the host community and supporting hostrefugee cooperation require further research and investigation.

\section{Notes}

1. Initially tractors were used, but this proved difficult because funds were unavailable for managerial costs. Eventually ox ploughs were employed instead.

\section{References}

Crowder, M. et al. (1970). Ancient Times: A junior history for Africa, London: Longman.

Government of Malawi (1990). "Report to the Consultative Group for Malawi on the Impact of Refugees on Government Public Expenditure Programme."

Harrell-Bond, B.E. (1986). Imposing Aid: Emergency assistance to refugees, Oxford: Oxford University Press.

Kibreab, Gaim (1987). "Rural Land Settlements in Eastern Sudan: On the Road to Self-Sufficiency?" in P. Nobel (ed) Refugees and Development in Africa, Seminar Proceedings No. 19, Uppsala: SIAS.

Mazur, R. (1986). "Linking Popular Initiatives and Aid Agencies: The case of refugees", Refugee Issues Vol. 3(2). Refugee Studies Programme, Oxford University.

Mwanza. A.M. and Seshemani, V. (1988). Refugees as an Important Aspect of the Human Dimension of Africa's Economic Crisis: Zambia case study. Paper presented at Silver Jubilee Conference of the African Studies Association, Cambridge, U.K., September.

UNHCR (1990). Country Progress Report: Malawi.

\title{
The Political Dynamics of Refugee Food Assistance in Malawi ${ }^{1}$
}

\author{
Agnès Callamard
}

The assistance that has been provided to Mozambican refugees in Malawi in the last five years is based on a "care and maintenance" approach. Its main objectives are to insure the protection of refugees and to implement life-saving activities. Central to the "care and maintenance" program (and indeed to all types of emergency assistance), is the delivery of food relief and of nonfood items, such as blankets, clothes and cooking pots. Up until 1993, the food assistance program in Malawi was hailed by international observers as successful in that it had avoided many of the pitfalls that had characterised similar programs in other parts of the world, such as corruption, continued insecurity and transport difficulties. As of 1993, however, the feeling regarding the program was somewhat different. In the course of a couple of months, the diversion, misuse and corruption of international food assistance had become a constant subject of conversation, scrutiny, investigation and tensions in the refugee camps as well as among national and international policy-makers. The situation in and outside the areas of settlement was in fact so serious that it led to a number of arrests for corruption, resignations among Malawian staff, and possibly the murder of a camp leader in Chifunga Refugee Camp.

The diversion and misuse of food relief or any type of international assistance in Malawi and elsewhere underlines the problematic interaction between international, national, and local actors, who are competing for the control of a principal source of political and economic power. Further, the ability of local actors (both refugees and

Agnes Callamard from France is a visiting research scholar at CRS, York University.
Malawians) to advance their own immediate economic interests and ultimately to impose a locally-based restructuring of "humanitarian" assistance has been facilitated by the existing international and national political uncertainty, and more importantly, mandated by the difficult economic and political reconstruction of the region.

\section{Food Assistance in Malawi: The Actors}

From 1987 onwards, World Food Program (WFP) has been the principal donor of basic food distributed to the refugees and has been responsible for the coordination of international and internal transport, storage and handling of the items distributed as well as the milling of maize. The quantity of food distributed is, in principle, determined by the number of refugees. Since 1990 , over 100,000 MT of cereal and non-cereal foodstuffs has been provided by WFP. Up to 1991, maize was purchased in Zimbabwe and Malawi but after this time, because of the 1991-92 drought in southern Africa, WFP had to rely on donations from the USA and European countries. WFP food assistance has been supplemented in the past by UNHCR special trust fund contributions for the local or regional purchase of food and for the milling costs of the maize. As of 1992, however, WFP assumed the responsibility for providing all food commodities, including sugar, salt and supplementary food previously purchased by UNHCR. ${ }^{2}$

The Malawi Red Cross Society (MRCS) is in charge of the distribution of food and non-food items, a fundamental function of the food relief program. Its operations, including the salary and training of staff, are funded 70 percent by the UNHCR under a 
tripartite agreement (MRCS/ UNHCR/Malawi government). The balance is funded by the International Federation of Red Cross Societies with a grant from the EEC. The distribution of food (and non-food) items occurs every two weeks in all 12 refugee-affected districts. All refugees presently hold a refugee card that indicates the number of persons in their family. This determines the amount of food received. The distribution is organized and supervised by employees of the MRCS with the assistance of refugee volunteers, also called "tippers." The volunteers, usually men, measure the various items with the help of a cup (for instance 1 cup $=280$ grams of beans) or bucket (1 bucket $=1 \mathrm{~kg}$ of flour) and fill up bags that refugees bring with them. The "food basket" consists in the following items distributed per refugee per fortnight: maize flour or $u f a(5.6 \mathrm{~kg})$, beans or peas $(0.84$ $\mathrm{kg})$; oil (1 tin per family); sugar (0.28 $\mathrm{kg})$, salt $(0.07 \mathrm{~kg})$ and groundnuts $(0.28$ $\mathrm{kg}$ ).

In theory, the ration should constitute a total of $2000 \mathrm{cal} /$ day per person, a standard suggested by the UNHCR nutritionist and agreed upon by the government, UNHCR and WFP at a Food Aid Co-ordination Unit meeting. But the food monitoring administered

\begin{tabular}{|lc|}
\hline \multicolumn{2}{|c|}{ Table 1: Average Caloric Ration } \\
in 1990, by Refugee Camps \\
Refugee Camp & Energy Content (cal. \\
Changambika & 1,901 \\
Chifunga & 2,034 \\
Chiringa & 1,566 \\
Kamphata & 1,643 \\
Kunyenda & 1,915 \\
Lilongwe & 1,622 \\
Mangochi & 1,630 \\
Mankhokwe & 1,693 \\
Muloza & 1,451 \\
Ntcheu & 1,609 \\
Nyamithutu & 1,780 \\
Tengani & 1,572 \\
Source: Center for Diseuse Control, \\
Review of Health and Nutrition \\
Program in Malawi, \\
November 1990, p.8. \\
\hline
\end{tabular}

by NGOs has revealed important discrepancies between the official food ration and the one actually received by refugees (Tables 1 and 2).

\section{Food Diversion and Reduction: International and Local Responsibilities}

The actual reduction and/or disappearance of food has occurred at two different levels of responsibility, namely international and local. Each have struggled to control the relief program.

The international level includes the first stage of the food assistance program, that is, the international mobilization of food items. In several instances, the international organizations (and hence the donor countries) have failed to supply the Malawian program with certain items or with the required quantity. Between December 1988 and June 1989, and again in 1990 , groundnuts for example have not been available for delivery to the refugees. The elimination of this item from the food basket is the direct consequence of a UNHCR budget crisis and the ensuing cuts in the Malawian program ( $\$ 6$ million in 1989 and 1990). These budget cuts resulted in the serious deterioration of refugee nutritional status and an outbreak of pellagra, a dermatological disease due to vitamin deficiency. Following publicising of the crisis through the French and American media by Médecins Sans Frontières(MSF), donaticns increased, allowing the partial re-introduction of groundnuts. More recently, in July 1993, WFP decided that in the up-coming months, sugar will not be included in the food basket distributed to the refugees. This decision followed the spontaneous return home of an unknown number of Mozambicans and occurred in the midst of much controversy surrounding the issue of repatriation. This decision was implicitly, if not explicitly, based on three grounds: a) to instigate "push factors" to encourage repatriation; b) to align the content of food ration in Malawi with the one in Mozambique; and c) to prevent the growth of an underground market in Malawian sugar within Malawi and the surrounding countries. The decision was indeed prompted by what was perceived by the international community in Malawi as the increasingly unmanageable abuse of the food assistance program by both refugees and local Malawians.

Diversion of food rations at the local level has been a recurrent, if not endemic problem of the food assistance program in Malawi from its onset. Up until the beginning of 1993 , it was perceived by most international and national actors as a manageable problem and a "normal" state of affairs that did not jeopardise the health and nutritional status of refugees, nor threaten the overall objectives of the program. Referred to as "under-tipping" (and alternatively "over-tipping"), this "misuse" of food relief takes place during the distribution of food itself. It underlines the stratification and power-making process occurring within the refugee camp and the fundamental role played by international assistance in fostering this process. ${ }^{3}$ The "tippers" (volunteer refugees who dole out the ration) reduce or increase the quantity of food they are in charge of distributing, depending on the identity of the refugees. In collusion with local Red Cross workers and section leaders to whom they
Table 2: Average Caloric Ration in 1992 (cals.) Refugee Camp Jan. Feb. March April May June $\begin{array}{lllllll}\text { Chifunga } & 1,701 & 1,832 & 1,978 & 1,728 & 1,643 & 1,526\end{array}$ $\begin{array}{lllllll}\text { Lisongwe } \quad 1,953 & 2,099 & 1,700 & 1,743 & 1,578 & 1,926\end{array}$ $\begin{array}{llllll}\text { Ntcheu } & 1,809 & - & - & -1,774 & -\end{array}$ $\begin{array}{lllllll}\text { Kunyenda } & 1,800 & 1,656 & - & - & - & -\end{array}$

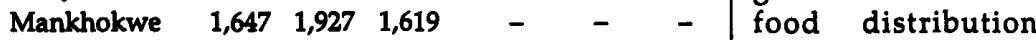
Source: MSF Monthly Report, 1992/ (from sampled camps only) witnessed by the tippers privilege themselves, friends, family members and section leaders at the owe their position, the witnessed by the
writer in the summer 
of 1992, one refugee who happened to be a section leader was first given 3 times the ration he was supposed to receive. (Because of the presence of NGO workers, his sack was then emptied and the food re-distributed). Out of 30 ufa rations sampled on this day, 24 were under the required amount, and for six of them more than $7 \mathrm{~kg}$ of ufa were missing."

Since the first months of 1993 when spontaneous repatriation began, international organizations and NGOs in Malawi have become increasingly alarmed with the scale of food diversion and with what is being perceived as the misuse of food assistance. While under-tipping is still widely practiced, it is exacerbated by the disappearance of important stocks of food (often at the distribution points themselves) and an unprecedented underground market in refugee ration cards. Research conducted in the summer of 1992 indicated that these activities were already taking place then, but at a lower rate. From the first months of 1993 onwards, their scope has indeed increased to include refugees and Malawians who in the past could not have engaged in them, or refrained from doing so; a phenomenon that could be referred to as the "democratization of diversion." An actual quantitative assessment of the outcome of the practices is difficult, but some sources in Malawi suspect that up to 30 percent of the food and non-food items distributed were diverted. According to investigation conducted in sections of Lisongwe refugee camp by some officials, 35 percent of the families were not living in the camp any more but were nevertheless included in the food assistance program. ${ }^{5}$ The intensification of these activities has taken place along three main avenues.

First, returnees who have returned to Mozambique near the Malawian border have kept their ration cards and return every two weeks to the distribution points in Malawi to receive food rations. This phenomenon is especially prevalent in the self-settlements of Ntcheu and Dedza where most refugee huts are now deserted. The area now resembles a ghost town, except on distribution days when returnees living in the Angonia district of Mozambique cross the border to collect food and non-food items.

Second, a number of refugees returning to Mozambique are selling, giving, or possibly being coerced into surrendering their ration cards to the remaining refugees, predominantly but not exclusively to section leaders, allowing them to increase their food rations later assigned to home consumption, sale or barter. The extent of the practice is difficult to quantify but all refugees interviewed during fieldwork in Lisongwe camp admitted "knowing somebody" who had at least two ration cards, and in some cases up to fifty. Further, in the course of investigating the intensive feeding center, 14 percent of sampled refugees were in possession of two or more ration cards. ${ }^{6}$ To the extent that these refugees can be counted among the "vulnerable" and that refugees are, understandably, very reluctant to admit to the practice, this figure certainly underestimates the extent of the trade.

Third, local Malawians in charge of the delivery of food relief are now diverting important quantities of food from its original destination. While this type of activity did occur in the past, spontaneous repatriation has led to an explosion of such activity in three main ways. In the first place, spontaneous repatriation made the task of "counting" refugees more difficult than it already was, because of practices mentioned above and/or the vested interests of the Malawian employees and representatives of OPC (Office of President and Cabinet) to keep the official count high. For instance, in June 1993, OPC estimated that the population of Luwani camp was 35,427 individuals, compared to the figure of 22,462 compiled by the Health Surveillant Assistants (HSA) for MSF. $^{7}$ Second and consequently, the discrepancy between the official and the actual number of refugees allowed local Malawians and Mozambicans involved in the distribution process to increase the quantity di- verted. Third, and most importantly, spontaneous repatriation and therefore the imminent closure of refugee camps, acted as a push factor in terms of risk-taking. In an environment dominated by unemployment, poverty, political uncertainty and the absence of economic opportunities, Malawians (from local government officials to Red Cross employees) are taking more risks than they have in the past, in anticipation of their imminent unemployment.

As this brief review underlines, the spontaneous return of refugees to Mozambique fostered conditions for the emergence and development of all three activities. Additionally, the ambiguous and delayed implementation of repatriation and reconstruction programs $^{8}$ facilitated the adoption of the strategies described above. In other words, the frequent movements of Mozambican returnees across the Malawian border and the trade of refugee cards-which has to a large extent impeded the shifting of food assistance from Malawi to Mozambique-also result from a repatriation policy based on spontaneous return and more importantly on the absence of repatriation assistance (such as the provision of transport or cash). According to the repatriation plan of action, refugees in Malawi are supposed to return to Mozambique "spontaneously" and without assistance, in contrast to those in Zimbabwe (and eventually in South Africa) for whom repatriation has been (or will be) of an organised form.

Refugees are spontaneously returning, but it is disputed as to just how many of them have done so. In July 1993, the UNHCR office in Tete estimated that in the first six months of the year, 215,000 refugees had gone back to Tete province from Malawi; a figure strongly disputed in Malawi itself. Even if the above figure of returnees is correct, this does not signify however that these refugees/returnees are not coming back to the camp in Malawi to collect their food rations, a situation that explained the major discrepancy between the figures compiled in $\mathrm{Ma}$ lawi and Mozambique. Return of refu- 
gees is self-organized and follows a strategy that best suits their interests; a strategy that maximizes their chances of physical, economic, and political survival and necessitates for a number of them to challenge an identity (refugee or returnee?) imposed upon them by international standards by crossing the Malawian border on a bi-monthly basis.

As far as these movements are concerned, one obvious way to put an end to them would have been to distribute food assistance on the same day on both sides of the border. The absence of such a regional-based organization of food relief underlines the difficulties that international organizations have faced in coordinating their activities. The lack of coordination and cooperation among relief partners constitutes one of the most persistent problems of humanitarian assistance programs and one that has often impeded their realisation and success.

In theory, coordination mechanisms should be established at the onset of a program to allow and facilitate coordination and cooperation at three different levels: among the different agencies of the United Nations, among the implementing partners (international and national NGOs as well as national governments) and between these two.

In practice, however, one or several units of implementation tend to operate in isolation from each other, with no coordination framework in place, or one which is too frail to constrain the activities of the respective actors. On a regional basis, the problems of coordination are often made worse by communication problems and the large number of international and national agencies involved in assisting the refugees. Excessive numbers of agencies multiply the risks of duplicating relief activities and experiencing personality conflicts, as well as conflicts over funding. All such risks currently influence the politics of repatriation and reconstruction in Mozambique, along with, or because of, the climate of uncertainty regarding the maintenance of peace.

\section{Concluaton}

The diversion and disappearance of food relief in Malawi demonstrates the problematic interaction and potential conflicts between local and international interests. Most importantly, it is also a reflection of the numerous problems facing a country and in fact a whole region in the process of political and economic reconstruction. As such, these diversions do serve a "humanitarian" purpose, whether or not it was the one originally conceived and organised within international circles.

In the final analysis, one wonders whether the approaches and humanitarian purposes adopted by refugees and international actors are as dissimilar and conflicting as they appear to be in the field. The strategies of reluctance and procrastination, incessant movement and trading of assets may be grounded in the same principle for both refugees and international actors: to wait and see. As a returnee mentioned in Mozambique, 9

RENAMO and FRELIMO are on holidays right now. They are eating a lot and getting fat. We don't know what they will do at the end of their vacations.

\section{Notes}

1. This paper is based on fieldwork conducted in Malawi and in Tete province of Mozambique in the summers of 1992 and 1993.

2. UNHCR, Country Briefing Note, 1991, Malawi, p.4.

3. This stratification process is largely gender-based in that it privileges men at the expense of women. See Agnès Callamard Food is Power: The Reconstruction of the Gender Division of Labour in Refugee Camps, a paper presented at the conference on "Gender Issues and Refugees: Development Implications," Center for Refugee Studies, Toronto, May 1993.

4. Fieldwork notes, July 1992

5. Fieidwork notes, summer 1993 .

6. Fieldwork notes, summer 1993.

7. Médecins Sans Frontières, Monthly Report June 1993, Malawi.

8. See Olaf Tataryn in this issue.

9. Fieldwork notes, Tete province, Mozambique, Summer 1993.

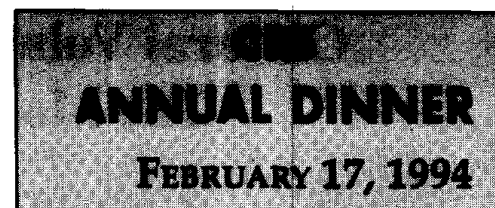

The Centre for Refugee Studies (CRS) cordially invites you and your friends to join is at our Annual Dinner. It is being held on Thureday, February 17, 1993 at the Jede Garden Restourant, 222 Spadin Avehue, Toronto.

This year's dinner will focus on teliglous and other benevo. lent organizations that have provided assiotance in extending Canade's welcome to refugees, and the annual Vincent Kelly Awand for outstandingservice to refugees will be presented to an organization from this focus group.

\section{CRS Endowment hond}

Our annual dinner is an opportunity for the Centre to bring together those interested and involved in refugee studies. The proceeds from this year's dinner will asdist in funding two gradu. ale students with their research through the CRS Endowment Fund.

We look forward to you joining us or your finandal support through a donation, which will enable people from the refugee community to attend our dinner on your behalf.

flease complete a copy of the registration form in page 27 and sendit to us at youz earliest convenience. The CRS greatly appreclates your interest and suppost of our endenvours For further information, plepse contact: Helen Groos Centre for Refures studies Suite 322 , York 1 mo. You Univarity 700 reele ste.

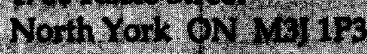
6)(115) 23 it (14) 73

Refuge, Vol. 13, No. 6 (October 1993) 